\title{
Development of a Phytocosmetic Enriched with Pequi (Caryocar brasiliense Cambess) Oil
}

\author{
Giovana Sant'Ana Pegorin 1,2* \\ https://orcid.org/0000-0003-3817-8202 \\ Márcia Ortiz Mayo Marques ${ }^{3}$ \\ https://orcid.org/0000-0001-8270-4308
}

\section{Cassia Roberta Malacrida Mayer ${ }^{4}$}

https://orcid.org/0000-0003-0069-6581

\section{Lucinéia Santos ${ }^{4 *}$}

https://orcid.org/0000-0002-9142-0371

\begin{abstract}
${ }^{1}$ São Paulo State University, Institute of Chemistry, Department of Biochemistry and Organic Chemistry, Araraquara, São Paulo, Brazil; ${ }^{2}$ São Paulo State University, School of Pharmaceutical Sciences, Bioprocess and Biotechnology Department, Araraquara, São Paulo, Brazil; ${ }^{3}$ Agronomic Institute of Campinas (IAC) - Center for Research and Development of Plant Genetic Resources, Campinas, São Paulo, Brazil; ${ }^{4}$ São Paulo State University, School of Sciences and Languages, Biotechnology Department, Assis, São Paulo, Brazil.
\end{abstract}

Received: 2019.08.06; Accepted: 2020.06.01.

*Correspondence: lucineia.santos@unesp.br; Tel.: +55-18-33025610 (L.S.); giovanapegorin@gmail.com (G.S.P.)

\section{HIGHLIGHTS}

- Pequi oil showed high percentages of palmitic and oleic fatty acids.

- Pequi oil did not present cytotoxicity in mouse fibroblast cells.

- Phenolic compounds content found in the pequi oil cream was relatively high.

- The pequi oil cream obtained an $\mathrm{EC}_{50}$ value equal to $2.921 \mathrm{mg} / \mathrm{mL}$.

Abstract: The pulp oil of Caryocar brasiliense Camb., better known as pequi, is used in the typical cuisine of the Brazilian Cerrado region. It is also used in folk medicine to combat several types of disease of the respiratory system and skin. However, since its exploration is purely extractive, the exhaustion of this plant is already foreseen. Thus, in order to establish the sustainable use of pequi and contribute to its maintenance, this study aimed to develop a phytocosmetic with antioxidant and photoprotective properties using the oil of this fruit. Initially, the cytotoxicity of the oil was evaluated in order to establish the safety of its use and its fatty acid composition. Then, from the cream enriched with the oil, it was evaluated the antioxidant and photoprotector potentials, quantified the total phenolic content and examined the quality of the formulation. Pequi oil showed high percentages of palmitic $(52.11 \%)$ and oleic $(44.57 \%)$ fatty acids and absence of cytotoxicity. The analysis of the cream revealed $168.8 \mathrm{mg}$ of total phenols in gallic acid equivalent per $100 \mathrm{~g}$ of oil. The evaluation of antioxidant activity showed an $\mathrm{EC}_{50}$ of $2.921 \mathrm{mg} / \mathrm{mL}$ and a capacity of inhibiting the lipoperoxidation process higher than $100 \%$. The obtained sun protection factor was 11.40 at the concentration of $6.25 \mathrm{mg} / \mathrm{mL}$. The quality tests revealed small disturbances in the cream stability that can be solved by 
further research and improvement of the formulation. The pequi oil can be converted into a phytocosmetic of great commercial value.

Keywords: antioxidant; UV protection; pulp oil; Caryocar brasiliense Cambess; preservation; sustainability.

\section{INTRODUCTION}

Phytoconstituents are becoming popular as ingredients in cosmetic formulations because they can protect the skin against exogenous and endogenous harmful agents. This is because plant extracts are multifunctional in nature. In other words, they possess several properties such as photoprotection, antiaging, moisturizing, antioxidant and antimicrobial, which results from the presence of various active natural compounds in these extracts, such as polyphenols, monoterpenes, flavonoids, organosulfides and indoles [1], which could have synergetic effects and present less toxicity [2].

In the cosmetic industry, the vegetable oils, an abundant renewable and readily available resource mainly derived from seed waste, exhibit a great interest as raw materials in the development of natural and ecofriendly cosmetics [3,4]. The oils can provide skin protection against reactive oxygen species (ROS) because of natural antioxidants present in them, such as tocols, triterpene, carotenoids, flavonoids and polyphenols [5-7]. In cosmetic formulations, oils are used as moisturizers and emollients by increasing the hydration of the skin [8,9]. Thus, besides their main role as natural constituent of the lipid fraction, vegetable oils also have multiple skin benefits and a therapeutic activity by counteracting the oxidative stress. Actually, many scientists are exploring natural compounds of plant origin that are capable of absorbing UV radiation and possess photoprotective activity. Polyphenols, especially flavonoids, have been widely explored for radiation absorptive properties [10].

Considering the importance of plant extracts in cosmetology and the richness of plant species in Brazil, an important biome to be studied is the Brazilian Cerrado. This biome presents an enormous biodiversity, similar to the most exuberant tropical forests. However, the high level of endemism and devastation of vegetation cover, mainly due to the deforestation caused by the expansion of pastures and soybean and sugarcane crops makes the Cerrado a hotspot. This concept reveals the situation of ecosystems whose species are seriously threatened by human activities [11]. In front of this scenario of the Cerrado biodiversity, there is the plant Caryocar brasiliense, also known as pequi. It is a native species of the Brazilian Cerrado, and can be found from the Amazon to São Paulo [12-15]. Inside its fruit there is a seed covered by a soft and yellow edible pulp. Under the pulp, there is a thorny endocarpus that protect an edible, soft and tasty almond [16]. The pequi pulp oil, which has higher added value than the fresh fruit because it is used in regional culinary, is produced by pulp pressing or hot water extraction. In addition, it is known that this oil has a toning effect and is used in folk medicine to combat various types of respiratory diseases (bronchitis, colds and flu), to treat inflammatory and tumoral processes of the skin and ophthalmic problems [15,17], as well as the treatment of burns [18]. Bezerra and coauthors [19] verified healing activity in cutaneous lesions of rats by administering pequi pulp oil. In this way, pequi is considered the plant of greater economic interest of the Cerrado, constituting an important source of income for some communities [20-22]. However, the extractive activity of the pequi fruit combined with the advance of large monoculture crops [23] may lead to the extinction of this plant in a very near future if measures to valorize the pequi are not taken [12]. Between 1990 and 2008 , the social cost of the decrease in the native population of pequi trees, caused by deforestation of the biome, was estimated at $R \$ 922,000$ per year, equivalent to $48 \%$ of the benefits generated by the commercialization of the pequi fruit in the same period [24].

Considering that pequi fruit can be converted in products of high commercial value due to its important therapeutic properties $[25,26]$ and contribute to the valorization and preservation of the Cerrado biome, the main objective of this study was to develop an antioxidant and photoprotective formulation enriched with pequi pulp oil, in the form of cream. For this purpose, therapeutic activities, toxicity and quality control tests were performed to ensure the product safety. In addition, in order to establish a relationship between the pharmacological actions and the chemical composition of the pequi oil, phytochemical analysis was performed. 


\section{MATERIAL AND METHODS}

\section{Obtaining the pequi pulp}

The pequi fruits were obtained from the city of Mirabela, state of Minas Gerais, in the Brazilian southeast region (latitude: 16ำ 15 '46' 'S; longitude: 44 09' 52 " W, altitude: $800 \mathrm{~m}$ ). The fruits were first washed and peeled. Then, the pulp (inner mesocarp) was separated from the endocarp, packed in plastic bags and stored under refrigeration $\left(-18^{\circ} \mathrm{C}\right)$. The species under study was identified as Caryocar brasiliense Cambess in the Herbarium Assisense (HASSI) of the São Paulo State University where a voucher specimen was deposited under the number 1998.

\section{Oil extraction from the pequi pulp}

In order to obtain the pequi pulp oil, the pulp was manually cut in small pieces and dried in a forced air oven at $40^{\circ} \mathrm{C}$ for $24 \mathrm{~h}$. The oil extraction was performed using a mini hydraulic press (PH 10, Nowak, Brazil) with an applied force of $0.5 \mathrm{ton} / \mathrm{cm}^{2}$ for $1 \mathrm{~h}$. After that, the obtained oil was weighed in order to calculate the yield, then it was packed in an amber glass bottle and stored in a freezer $\left(-18^{\circ} \mathrm{C}\right)$ for further analysis.

\section{Analysis of fatty acids in the pequi pulp oil}

Initially, by the transesterification procedure of pequi oil, the methyl esters of the fatty acids were prepared according to the method described by Maia [27]. The lipid extracts (60 $\mathrm{mg}$ ) were saponified in a screw cap test tube containing $5 \mathrm{~mL}$ of methanolic solution of sodium hydroxide $(0.5 \mathrm{~N})$ at $90^{\circ} \mathrm{C}$ for 5 min. The fatty acids were methylated using $4 \mathrm{~mL}$ of a solution containing ammonium chloride, sulfuric acid and methanol in a ratio of $1: 1$ and 5:30, respectively, under heating $\left(90^{\circ} \mathrm{C}\right)$ for 5 min. Subsequently, $4 \mathrm{~mL}$ of saturated sodium chloride solution were added to the test tube under stirring ( $30 \mathrm{~s})$ and, finally, it was added $5 \mathrm{~mL}$ of hexane (Tedia, chromatography grade). After the phases being separated, the upper phase (hexane phase) was transferred to a flask with cap using a Pasteur pipette and it was kept under refrigeration. Afterwards, the qualitative analysis of the methyl esters was carried out in a gas chromatograph coupled to a mass spectrometer (GC-MS, Shimadzu, QP-5000), operating by electron impact (70eV), and the quantitative analysis was performed in a gas chromatograph with flame ionization detector (GC-FID, Shimadzu, GC2010/AOC-20i), both with fused-silica capillary column OV-5 (Ohio Valley Specialty Chemical, Inc. $30.0 \mathrm{~mm} \times 0.25 \mathrm{~mm} \times 0.25 \mu \mathrm{m})$, helium as carrier gas $(1.7 \mathrm{~mL} / \mathrm{min})$, injector at $240{ }^{\circ} \mathrm{C}$, detector at $230^{\circ} \mathrm{C}$ and split $1 / 30.1 \mu \mathrm{L}$ of the hexane phase was injected in the following temperature program: $110^{\circ} \mathrm{C}(1 \mathrm{~min})$, $110^{\circ} \mathrm{C}-170^{\circ} \mathrm{C}, 10^{\circ} \mathrm{C} / \mathrm{min} ; 170{ }^{\circ} \mathrm{C}(2 \mathrm{~min}) ; 170^{\circ} \mathrm{C}-173^{\circ} \mathrm{C}, 1.5^{\circ} \mathrm{C} / \mathrm{min} ; 173^{\circ} \mathrm{C}-180^{\circ} \mathrm{C}, 1^{\circ} \mathrm{C} / \mathrm{min} ; 180^{\circ} \mathrm{C}(7$ $\min ) ; 180^{\circ} \mathrm{C}-230^{\circ} \mathrm{C}, 6^{\circ} \mathrm{C} / \mathrm{min} ; 230^{\circ} \mathrm{C},(20 \mathrm{~min})$. The substances were identified by comparing the retention time and mass spectrum to the standards of the methyl esters of the following fatty acids: oleic (Sigma, L37H846), palmitic (Sigma, L-80H8431), linoleic (Serva L-27908), myristic (L-126H3446) and stearic (Sigma, $\mathrm{L}-26 \mathrm{H} 8491)$, analyzed under the same operating conditions of the samples.

\section{Determination of cytotoxicity of the pequi pulp oil by MTT assay [3-(4,5-dimethylthiazol-2-yl) -2,5- diphenyltetrazolium bromide]}

This assay was performed according to the protocol described by Mosmann [28] with some modifications [29].Using a 96-well cell culture plate, $3 \times 10^{4}$ mouse fibroblast cells were seeded in 25 wells, in five replicates. Cells were incubated in culture medium for a period of $24 \mathrm{~h}$ at $37{ }^{\circ} \mathrm{C}, 5 \% \mathrm{CO}_{2}$. After a confluence of approximately $75 \%(24 \mathrm{~h})$, these cells were exposed to three different concentrations of pequi oil $(50 \%, 25 \%$ and $12.5 \%$ oil dissolved in $0.5 \%$ DMSO), to the negative control (physiological solution with $0.5 \%$ DMSO) and the positive control ( $2 \%$ Tween 80 ). The treatment time was of $24 \mathrm{~h}$. After this time, the culture medium was removed, $750 \mu \mathrm{L}$ of MTT solution (CAS 298-93-1, Sigma Aldrich - $0.005 \mathrm{~g} \mathrm{MTT,} 5 \mathrm{~mL}$ PBS, $10 \mathrm{~mL}$ culture medium serum-free) was added in each one of the 25 wells and it was incubated for $4 \mathrm{~h}$ at $37{ }^{\circ} \mathrm{C}, 5 \% \mathrm{CO}_{2}$. Then, the MTT was discarded and DMSO was added to each well in order to solubilize the formazan crystals. Finally, the absorbance was measured using a UV-vis spectrophotometer (Thermo Scientific Multiskan FC type 357) at $560 \mathrm{~nm}$.

\section{Development of pequi oil cream formulation}

A nonionic emulsion was developed consisting of two phases, an oily and an aqueous. Preservatives suitable for bases and cosmetic assets already known and used in Brazil [30] were used. The oil phase was 
composed of emollient agent (mineral oil 2\%) and emulsifier (polysorbate - polyoxyethylene sorbitan monoleate $2.5 \%$ - and cetostearyl alcohol $10 \%$ ) and the aqueous phase was composed of thickening agent (carbopol $0.5 \%$ ) and humectant (glycerine $4 \%$ ). To prepare the formulation the aqueous and oily phases were weighed in beakers and heated to $80^{\circ} \mathrm{C}$. Then, the aqueous phase was poured into the oil and the mixture was emulsified under agitation at the same temperature for approximately 10 min until cooling $\left(20-25^{\circ} \mathrm{C}\right)$ $[31,32]$. To prepare the cream with pequi pulp oil, the oil was added to the oil phase at $5 \%$ concentration $(\mathrm{w} / \mathrm{w})$.

\section{Determination of total phenolic content of the pequi oil cream}

In order to analyze the concentration of total phenols in the cream enriched with pequi oil, it was used the Folin-Ciocalteau method according to Singleton and Rossi [33], using Gallic acid as standard for the calibration curve. It was added $5 \mathrm{~mL}$ of distilled water and $0.25 \mathrm{~mL}$ of the Folin-Ciocalteau reagent (molybdate, tungstate and phosphoric acid) to each $0.5 \mathrm{~mL}$ of the pequi oil cream sample dissolved in ethyl alcohol (3.12 $\mathrm{mg} / \mathrm{mL})$. After $3 \mathrm{~min}, 1 \mathrm{~mL}$ of $10 \%(\mathrm{w} / \mathrm{v})$ saturated $\mathrm{Na}_{2} \mathrm{CO}_{3}$ solution was added and the mixture was left to rest for $1 \mathrm{~h}$. The absorbance was measured at $725 \mathrm{~nm}$ using a UV-Vis spectrophotometer (FEMTO $800 \mathrm{XI}$ ). Under the same conditions, the sample volume was replaced by gallic acid solutions at increasing concentrations of $10,25,50,75$ and $100 \mu \mathrm{g} / \mathrm{mL}$, obtaining the calibration curve. The test was performed in triplicate, the results were obtained from the calibration curve constructed previously and they were expressed as mg of gallic acid equivalent per $100 \mathrm{~g}$ of pequi oil present in the cream (mg GAE/100 g).

\section{Determination of flavonoids content of the pequi oil cream}

In order to analyze the concentration of flavonoids in the cream enriched with pequi oil it was used the method described by Serdar and coauthors [34] with some modifications. The calibration curve was constructed with quercetin as standard. A $0.5 \mathrm{~mL}$ aliquot of the pequi oil cream sample dissolved in ethyl alcohol $(3.12 \mathrm{mg} / \mathrm{mL})$ was mixed with $1.5 \mathrm{~mL}$ of ethyl alcohol and $0.1 \mathrm{~mL}$ of $10 \% \mathrm{AlCl}_{3}(\mathrm{w} / \mathrm{v}) .0 .1 \mathrm{~mL}$ of $1 \mathrm{M}$ $\mathrm{CH}_{3} \mathrm{COONa}$ (sodium acetate) was added and the tubes were filled up to $5.0 \mathrm{~mL}$ with distilled water. The tubes were then homogenized and kept in the dark for $30 \mathrm{~min}$. The absorbance was measured at $425 \mathrm{~nm}$ using a UV-Vis spectrophotometer (FEMTO $800 \mathrm{XI}$ ). Under the same conditions, the sample volume was replaced by quercetin solutions at increasing concentrations of $10,25,50,75$ and $100 \mu \mathrm{g} / \mathrm{mL}$, obtaining the calibration curve. The test was performed in triplicate, the results were obtained from the calibration curve constructed previously and they were expressed as $\mathrm{mg}$ of quercetin equivalent per $1 \mathrm{~g}$ of pequi oil present in the cream (mg EQ/1 g).

\section{Evaluation of the antioxidant activity of the pequi oil cream}

\section{$D P P H^{\circ}$ method}

This analysis was carried out by sequestration of 2,2-diphenyl-1-picryl-hydrazyl radicals (DPPH ${ }^{\bullet}$. This method consists of reducing the absorbance values in the wavelength of 515 to $530 \mathrm{~nm}$ due to the action of antioxidants added to an alcoholic solution of the $\mathrm{DPPH}^{\bullet}$ [34]. The experiments were performed in triplicate for statistical purposes, using $1 \mathrm{~mL}$ of the cream samples with different concentrations of pequi oil $(6.25 ; 3.12$; 1.56 and $0.78 \mathrm{mg} / \mathrm{mL}$ ) and $1 \mathrm{~mL}$ of the $\mathrm{DPPH}^{\bullet}$ solution, both dissolved in methyl alcohol. The cream samples reacted with the $\mathrm{DPPH}^{\bullet}$ for $30 \mathrm{~min}$ in the dark. The solution was then analyzed using a UV-Vis spectrophotometer (FEMTO $800 \mathrm{XI}$ ) at a wavelength of $517 \mathrm{~nm}$. As negative control (CN) was used a cream sample without pequi oil and as blank was used methyl alcohol. Under the same conditions, the standard curve was performed using quercetin as the reference standard at concentrations of 1 to $9 \mu \mathrm{g} / \mathrm{mL}$. The antioxidant activity of pequi oil cream was determined by its ability of sequestering DPPH ${ }^{\bullet}$ and was expressed in two ways:

1) Definition of the percentage of oxidation inhibition of the radical according to the equation below:

$$
\text { Antioxidant activity }(\%)=\left\{\left[\left(A_{C N}-A_{B}\right)-\left(A_{A}-A_{B}\right)\right] /\left(A_{C N}-A_{B}\right)\right\} \times 100
$$

Where: $A_{A}$ is the absorbance of the samples, $A_{C N}$ is the absorbance of the negative control and $A_{B}$ is the absorbance of the blank.

2) Determination of the effective concentration $E_{50}$, which represents the amount of antioxidant substance required to reduce by $50 \%$ the initial $\mathrm{DPPH} \mathrm{H}^{\bullet}$ concentration [35], that is, the concentration of pequi oil required to reduce the $\mathrm{DPPH}^{\bullet}$ to $50 \%$ of the total hydrazine. 
In this analysis, a regression curve was elaborated with the average values of antioxidant activity as a function of the different analyzed concentrations and a line equation could be obtained from that. From this equation, the antioxidant capability of sequestering the $\mathrm{DPPH}{ }^{\bullet}$ of the pequi oil cream was also expressed by the $\mathrm{EC}_{50}$ value.

\section{Lipid Peroxidation (LPO) method}

To evaluate the ability of pequi oil cream to inhibit the LPO process, an assay was performed according to the model proposed by Daker and coauthors [36], with modifications. The egg yolk was used as a source of lipids. Thus, $10 \mathrm{~g}$ of yolk was homogenized in $100 \mathrm{~mL}$ of phosphate buffer $0.1 \mathrm{M}$. Screw cap test tubes were filled with $0.5 \mathrm{~mL}$ of the previous mentioned solution, $0.4 \mathrm{~mL}$ of distilled water and $0.1 \mathrm{~mL}$ of the cream samples with different concentrations of pequi oil $(6.25 ; 3.12 ; 1.56$ and $0.78 \mathrm{mg} / \mathrm{mL})$ dissolved in ethyl alcohol. $0.1 \mathrm{~mL}$ of solution of 2,2'-azobis (2-amidinopropane) dihydrochloride (AAPH) $0.12 \mathrm{M}$ was added and incubated at $37^{\circ} \mathrm{C}$ for $30 \mathrm{~min}$. Finally, $1.5 \mathrm{~mL}$ of $20 \%(\mathrm{w} / \mathrm{v})$ trichloroacetic acid (TCA) and $1.5 \mathrm{~mL}$ of $1 \%(\mathrm{w} / \mathrm{v})$ thiobarbituric acid (TBA) were added. The resulting mixture was incubated at $95^{\circ} \mathrm{C}$ for $60 \mathrm{~min}$. Then, it was added $5.0 \mathrm{~mL}$ of butyl alcohol and it was centrifuged at $3500 \mathrm{~g}$ for $10 \mathrm{~min}$ (Thermo Scientific MEGAFUGE 16R Centrifuge). $1 \mathrm{~mL}$ of supernatant was withdrawn and measured in a UV-Vis FEMTO $800 \mathrm{XI}$ spectrophotometer at $532 \mathrm{~nm}$. As negative control, $0.1 \mathrm{~mL}$ of a solution containing the cream sample without the pequi pulp oil and dissolved in ethyl alcohol was analyzed. As positive control, $0.1 \mathrm{~mL}$ of a cream solution enriched with quercetin at the concentration of $0.2 \mathrm{mg} / \mathrm{mL}$ and dissolved in ethyl alcohol was used. The blank was made with only ethyl alcohol. In this method, the antioxidant activity was related to the ability of pequi oil cream to inhibit the lipid peroxidation process. This ability to inhibit the lipoperoxidation was calculated according to $\mathrm{Li}$ and coauthors [37] using the following equation:

$$
\text { Inhibition of lipidic peroxidation }(\%)=\left\{\left[\left(A_{C N}-A_{B}\right)-\left(A_{A}-A_{B}\right)\right] /\left(A_{C N}-A_{B}\right)\right\} \times 100
$$

Where: $A_{A}$ is the absorbance of the samples, $A_{C N}$ is the absorbance of the negative control and $A_{B}$ is the absorbance of the blank.

\section{Determination of the Sun Protection Factor (SPF) of the pequi oil cream}

The determination of SPF is a technique that proves the effectiveness of the sunscreen filters for the portion of the ultraviolet $B$ (UVB) radiation of the electromagnetic spectrum. With wavelengths of higher energy (290-320 nm), UVB is responsible for causing erythema in the skin and cellular changes that predispose to skin cancer. Thus, a very effective filter is one that is able to protect exposed skin against sunburn [38]. The methodology developed by Mansur and colleagues [39] for the determination of SPF is effective and fast, and has also shown a good correlation with the results obtained in vivo, allowing its use in preliminary evaluations of photoprotectors [40-42]. For the determination of the SPF spectrophotometric were performed readings of the diluted samples using the UV-Vis FEMTO $800 \mathrm{XI}$ spectrophotometer and, subsequently, the obtained absorbance values were applied to the equation below:

$$
S P F=C F x \sum_{290 \mathrm{~nm}}^{320 \mathrm{~nm}} E E(\lambda) x I(\lambda) x|(\lambda)|
$$

Where: SPF is sun protection factor, CF is correction factor equal to $10^{30}$, EE $(\lambda)$ is erythematogenic effect of solar radiation in each $\lambda, I(\lambda)$ is intensity of the solar radiation in each $\lambda$ and Abs $(\lambda)$ is absorbance in each $\lambda$. The EE $(\lambda)$ and I $(\lambda)$ values are previously known obtained from the literature.

The cream enriched with pequi oil was analyzed at the concentration of $5 \%(w / w)$. In addition, in order to verify a possible potentialization of the photoprotective effect of octyl methoxycinnamate in the presence of pequi oil, they were associated in the same formulation, both at $5 \%(\mathrm{w} / \mathrm{w})$ concentration. All emulsions were diluted in ethyl alcohol at the concentration of $6.25 \mathrm{mg} / \mathrm{mL}$ and subjected to scanning.

In this test, as a negative control was used the cream without the addition of pequi oil and as positive control methoxycinnamate, a synthetic UVB sunscreen, incorporated in a concentration of $5 \%(w / w)$. Ethyl alcohol was used as blank and the experiment was performed in triplicate.

\section{Preliminary quality evaluation of the pequi oil cream}

In this stage was analyzed the cream enriched with pequi pulp oil at $6.25 \mathrm{mg} / \mathrm{mL}$ concentration. As negative control was used only the cream without the addition of the pequi oil. 


\section{Accelerated stability test or centrifugation test}

After $24 \mathrm{~h}$ of the cream preparation, about $4.5 \mathrm{~g}$ of each of the creams were weighed into centrifuge tubes. The centrifugation test (Thermo Scientific MEGAFUGE 16R Centrifuge) was performed at room temperature with a rotational speed of $210 \mathrm{~g}$ for $30 \mathrm{~min}$. After this time, the cream samples were analyzed macroscopically by their appearance $[43,44]$. This test was performed in triplicate.

\section{Thermal stress test}

About $3.5 \mathrm{~g}$ of each cream was transferred into test tubes in triplicate. The tubes were submitted to thermal stress in a thermostat water bath (SOLAB SL 150/10) with temperature ranging from 40 to $80^{\circ} \mathrm{C}$, with elevation of $10^{\circ} \mathrm{C}$ every 30 min up to $80^{\circ} \mathrm{C}$. The creams were analyzed macroscopically by their appearance after reaching the room temperature [44].

\section{Determination of organoleptic aspects}

The evaluated organoleptic characteristics were appearance, color and odor. Three cream samples were stored at room temperature, three at $45^{\circ} \mathrm{C}$ in the oven (SOLAB SL-100) and another three at $4{ }^{\circ} \mathrm{C}$ in the refrigerator. Weekly, for a period of 28 days, an aliquot of the pequi oil cream was placed on watch glass for comparison with the control group. The appearance and color were evaluated visually and the odor directly through the smell $[43,44]$.

\section{pH evaluation}

The $\mathrm{pH}$ evaluation of the creams was performed weekly for the period of 28 days using a calibrated $\mathrm{pH}$ meter (MS TECNOPON mPA210). The measurements were carried out in a solution diluted in the ratio of $1: 10$ with distilled water, performed in triplicate, and three samples were stored at room temperature, three at $45^{\circ} \mathrm{C}$ in the oven and three at $4{ }^{\circ} \mathrm{C}$ in the refrigerator [45].

\section{Determination of spreadability}

A glass plate mold $(D=20 \mathrm{~cm}, e=0.3 \mathrm{~cm})$ with a central hole $(D=0.9 \mathrm{~cm})$ was placed on a glass plate support. Under this plate was placed a sheet of graph paper and a light source. The cream samples were introduced into the orifice of the plate and the surface was leveled with a spatula. Thereafter, the plate mold was removed. After $1 \mathrm{~min}$, it was calculated the covered surface by measuring the diameter in two opposite positions with the aid of a graph paper and then calculating the average diameter. This procedure was repeated until there were 4 overlapped glass plates. The surface covered by the sample and the weight of the last added plate were registered for each iteration [43]. The plates placed over the samples had the following weights: plate 1 presenting $284.97 \mathrm{~g}$; plate 2, $283.67 \mathrm{~g}$; plate 3, $295.93 \mathrm{~g}$ and plate 4, $296.45 \mathrm{~g}$. The spreadability $(\mathrm{Si})$, determined at room temperature, was calculated by the equation:

$$
\mathrm{Si}=\left(d^{2} \times \pi\right) / 4
$$

Where: $\mathrm{Si}$ is spreadability of the sample for weight $\mathrm{i}\left(\mathrm{mm}^{2}\right)$ and $\mathrm{d}$ is mean diameter $(\mathrm{mm})$.

\section{Statistical analysis}

Quantitative data were expressed as mean \pm standard deviation. Statistical analysis was performed using BioEstat ${ }^{\circledR}$ (version 5.0) software (Brazil).Statistical variations between groups were determined using one-way ANOVA analysis followed by Tukey post-test. Values of $p<0.05$ were considered significant.

\section{RESULTS AND DISCUSSION}

\section{Fatty acids present in the pequi pulp oil}

As shown by the Figure 1, pequi pulp oil is composed of palmitic $(52.1 \%$, peak 2$)$, oleic $(44.6 \%$, peak 3$)$ and stearic $(1.84 \%$, peak 4$)$ acids. According to recent studies, during the analysis of fatty acids profile of pequi pulp oil by GC-FID, high concentrations of palmitic (35.25 to $37.05 \%$ ), oleic (56.48 to 57.42 ) and stearic (2.11 to $2.12 \%$ ) acids were detected, as shown in this work $[46,47]$.

The importance of the vegetable oils characterization for the emulsions development was described by Penagos-Calvete and coauthors [48]. These authors analyzed the profile of the Sacha inchi (Plukenetia 
volubilis L.) oil and observed the presence of high concentrations of linolenic (48.39\%), linoleic (35.01\%), oleic $(9.34 \%)$, palmitic $(3.89 \%)$ and stearic $(2.80 \%)$ acids. They concluded that the physicochemical characterization of vegetable oil represents a starting point for the advanced formulation of several industries, such as cosmetics, pharmaceuticals and food. For example, in the cosmetic industry, palmitic acid is often used as an opacifier, surfactant, emulsifier, and emollient, and in cosmetic formulations at a concentration of up to $13 \%$ it is not considered to be a primary irritant, cumulative or sensitizer agent [49]. On the other hand, the oleic acid, because of its oxidation stability, is capable of retarding the process of rancification both at high and room temperatures. Therefore, as oils with large amounts of oleic acid are more stable, they can generate cosmetic formulations with adequate stability [49]. In addition, fatty acids are structural components of membranes, participate in processes that involve cell growth and differentiation, signal transduction, regulation of gene expression, besides acting as an energy source for metabolism. Thus, the presence of these fatty acids in the skin is essential for the maintenance of skin hydration, skin barrier and hydrolipidic mantle [50].

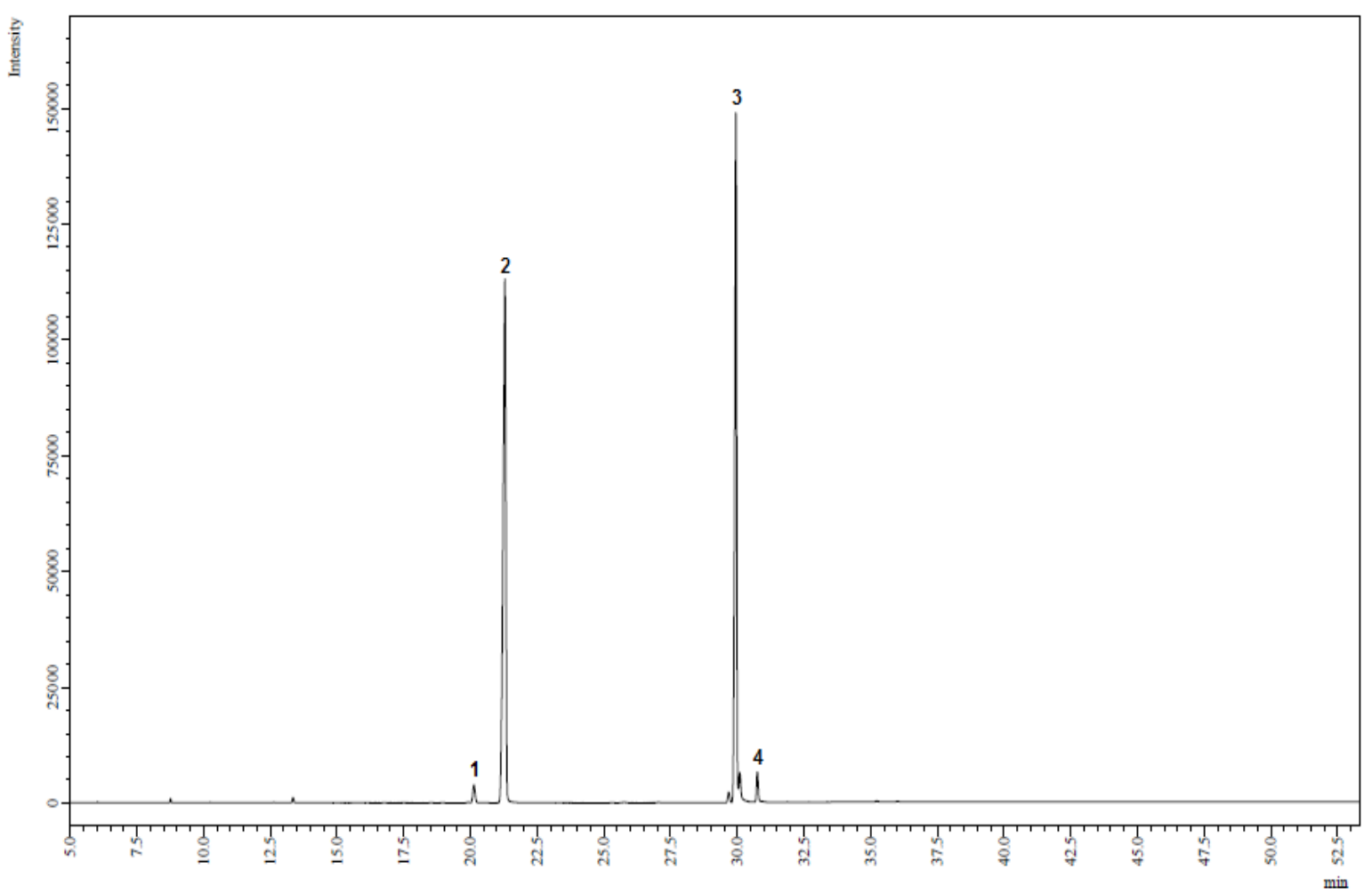

Figure 1. Chromatogram of pequi pulp oil obtained on gas chromatograph with flame ionization detector (GC/FID). Peak 1: $t_{R}=20.17$ min (unidentified), Peak 2: $t_{R}=21.33$ min (palmitic acid), Peak 3: $t_{R}=30$ min (oleic acid) and Peak 4: $t_{R}=$ $30.75 \mathrm{~min}$ (stearic acid).

\section{Pequi pulp oil cytotoxicity}

In the evaluation of the cytotoxicity of pequi oil, three groups were analyzed: positive control (Tween 80 $2 \%$ ), negative control (DMSO $0.5 \%$ ) and oil samples (50\%, $25 \%$ and $12.5 \%$ oil dissolved in $0.5 \%$ DMSO). The Figure 2 shows that the results obtained with pequi oil, at all the concentrations analyzed did not differ significantly in relation to the negative control. Thus, Tukey's post-hoc test shows that cell survival rates (represented by absorbance) were not affected by the pequi oil. On the other hand, the positive control differed significantly from the negative control, indicating that $2 \%$ Tween 80 is capable of promoting cell death (high toxicity represented by low absorbance value).

Despite of the lack of data about the pequi oil cytotoxicity in the scientific literature, a study by Ferreira and coauthors [51] using the Meyer method, pointed out that pequi oil presents cytotoxicity when in concentrations higher than $827.62 \pm 4.67 \mu \mathrm{g} / \mathrm{mL}$ in Artemia nauplii. In view of the fact that in this study the survival rate was higher than that of the negative control group, at all analyzed concentrations, it is evident the importance of future investigations in order to explain the in vitro toxicity of this oil, since these results differ from the expected by the literature. 


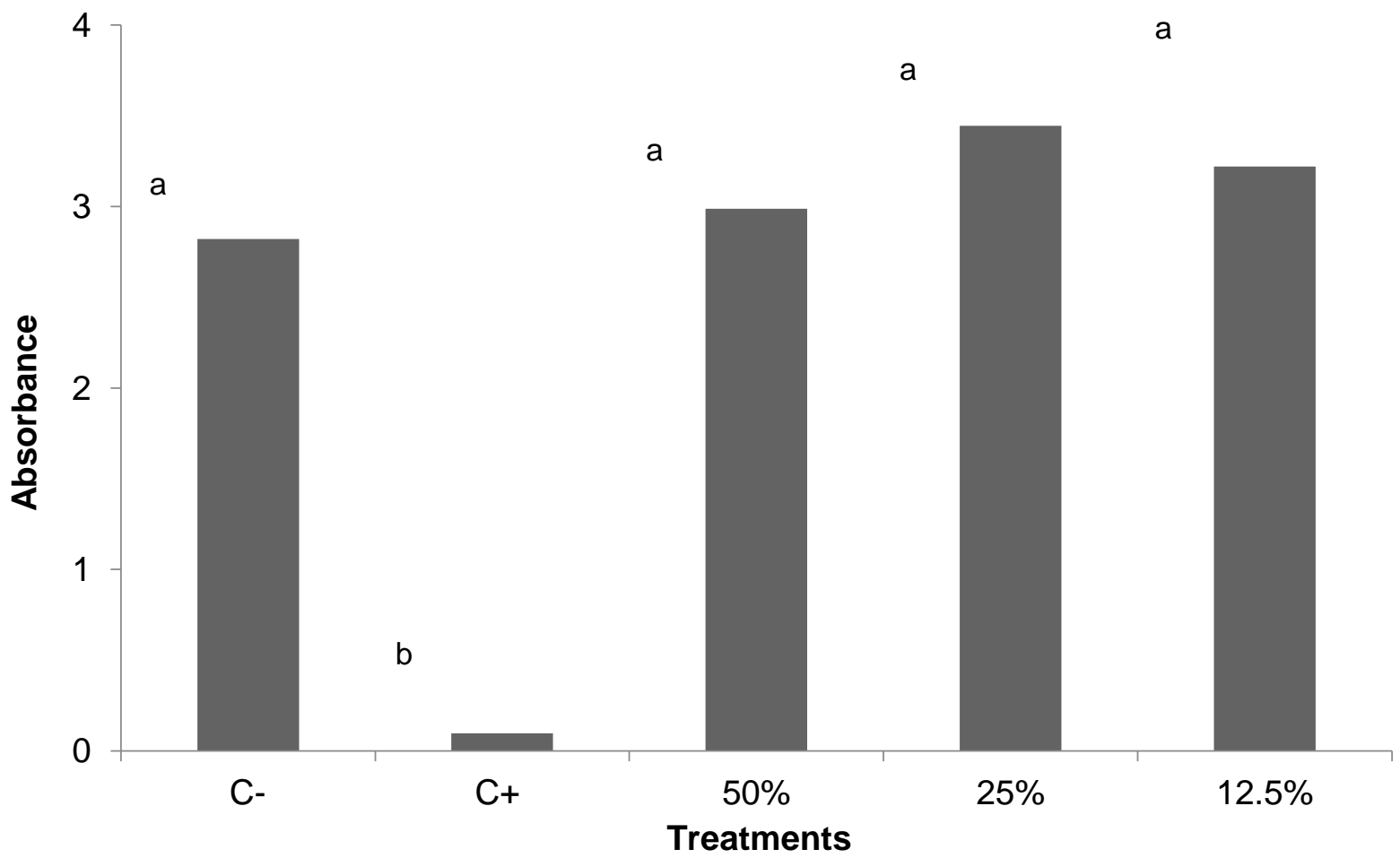

Figure 2. Mean $\pm \mathrm{DP}$ of the absorbance of the different treatment groups. The pequi oil was analyzed at concentrations of $50 \%, 25 \%$ and $12.5 \%$, dissolved in $0.5 \%$ DMSO. The $\mathrm{C}+$ group, positive control, represents the culture medium added with Tween 80 at $2 \%$ concentration, and the C- group, negative control, corresponds to the physiological solution with $0,5 \%$ DMSO. One-way ANOVA followed by the Tukey's post-hoc test. The different letters indicates if there was a significant difference $(p<0.05)$ between the group.

\section{Total phenolic compounds present in the pequi oil cream}

In order to analyze the concentration of total phenols in the cream enriched with pequi oil, a calibration curve was constructed using gallic acid as standard, generating following line equation: $Y=0.0104 . X+0.008$, with determination coefficient $\left(R^{2}\right)$ equal to 0.9919 . Then, the absorbance value of the sample of pequi oil cream $(3.12 \mathrm{mg} / \mathrm{mL})$ was inserted in this equation to obtain the concentration in milligrams of gallic acid. The results showed that pequi cream has high concentrations of phenolic compounds (163.24 $\pm 9.45 \mathrm{mg} \mathrm{GAE} / 100$ $\mathrm{g}$ pequi oil). That is, for every $100 \mathrm{~g}$ of pequi oil present in the formulation, $163.24 \mathrm{mg}$ of total phenolic compounds in gallic acid equivalents were detected.

In the literature, total phenolic compounds, in gallic acid equivalents, are reported in other vegetable oils, that were obtained by cold-pressing, such as soybean oil, pumpkin, hemp, pear-rio orange seed and guava seed, in the amounts of 1.48; 2.46;2.45; 4.91 e $92.3 \mathrm{mg}$ of gallic acid/100 g, respectively [52-54]. Furthermore, it has been reported that approximately $80 \%$ of phenolic compounds and tocopherols are removed from oils during the refining process, which involves sudden temperature conditions and chemical reagents [55]. The extraction by mechanical pressing of oils, especially in cold-pressing, tends to preserve the nutritional properties of the oils since it does not involve heating or subsequent chemical treatment [52, 56]. Thus, considering the capable of promoting health benefits, most oils should preferably be obtained by the cold mechanical pressing process [57], as in this study.

In relation to the concentration of phenols present in pequi pulp, from which the oil was extracted for this study, it has $209 \mathrm{mg} / 100 \mathrm{~g}$ of pulp, according to Lima and coauthors [16], higher than that found by the same researchers for most fruit pulp consumed in Brazil, such as: açaí (Euterpe oleracea Mart.), with $136.8 \mathrm{mg} / 100$ g; guava (Psidium guajava L.), with $83.1 \mathrm{mg} / 100 \mathrm{~g}$; strawberry (Fragaria ssp L.), with $132.1 \mathrm{mg} / 100 \mathrm{~g}$; pineapple (Ananas sativa L.), with $21.7 \mathrm{mg} / 100 \mathrm{~g}$; graviola (Annona muricata L.) with $84.3 \mathrm{mg} / 100 \mathrm{~g}$ and passion fruit (Passiflora edulis Sims.), with $20.2 \mathrm{mg} / 100 \mathrm{~g}$, being only inferior to acerola (Malpighia glabra L.), with $580.1 \mathrm{mg} / 100 \mathrm{~g}$, and mango (Mangifera indica L.), with $544 \mathrm{mg} / 100 \mathrm{~g}$. In short, the results presented in this study indicate that the pequi oil has a concentration of phenolic compounds much higher than the other oils and still maintains $78.10 \%$ of the concentration of these metabolites that are present in the pulp from which it was obtained. 


\section{Flavonoids present in the pequi oil cream}

In order to analyze the concentration of flavonoids in the cream enriched with pequi oil, a calibration curve was constructed using quercetin as standard, resulting in the following line equation: $Y=0.0082 . X$ 0.0039 , with determination coefficient $\left(R^{2}\right)$ equal to 0.9999 . Then, the absorbance value of the sample of pequi oil cream $(3.12 \mathrm{mg} / \mathrm{mL})$ was inserted in this equation to obtain the concentration in milligrams of quercetin. The results showed that pequi cream has high concentrations of flavonoids $(76.65 \pm 1.21 \mathrm{mg} \mathrm{QE} / 1$ $\mathrm{g}$ pequi oil). That is, for every $1 \mathrm{~g}$ of pequi oil present in the formulation, $76.65 \mathrm{mg}$ of flavonoids in quercetin equivalents were detected.

According to the literature, the flavonoids content are reported in some vegetable oils as follows, in decreasing order: to Finola hemp seeds oil (cold-pressing), $278.04 \mathrm{mg} \mathrm{QE/g} \mathrm{[58];} \mathrm{to} \mathrm{Persea} \mathrm{americana} \mathrm{Mill.}$ (avocado) seed oil (solvent extraction), $80.00 \pm 1.41 \mathrm{mg} \mathrm{QE} / \mathrm{g}$ [59]; to Pistacia lentiscus L. (aroeira) oil (coldpressing), $13.76 \pm 0.58 \mathrm{mg} \mathrm{QE} / \mathrm{g}$ [60]. The cashew nut (Anacardium occidentale L.) oil showed flavonoids content around $17.39 \pm 1.80,10.72 \pm 0.11$ and $9.49 \pm 0.98 \mathrm{mg} \mathrm{QE} / 100 \mathrm{~g}$ of oil extracted by cold-pressing, by solvent method and by enzyme assisted aqueous extraction, respectively [61]. These results again prove that cold-pressing is considered as a method that helps to preserve the content of bioactive compounds. Besides that, it was reported that the extraction technique significantly affects the content of bioactive compounds [62].

In relation to the concentration of flavonoids present in pequi pulp, according to the literature, the concentration found was $741.2 \pm 1.41 \mathrm{mg} \mathrm{QE} / 100 \mathrm{~g}$ or $7,412 \mathrm{mg} \mathrm{QE} / \mathrm{g}$ of dry sample [63].

In short, the results presented in this study indicate that the flavonoids content found in the pequi oil cream was relatively high when compared to other oils, except Finola hemp seeds oil and avocado oil. However, as the values of flavonoids found in the pequi pulp [63] were much lower than that found in this study, it is likely that the cosmetic formulation caused interference in this analysis. It has been described that excipients and adjuvants present in cosmetic formulations can interfere with the quantification of flavonoids [64].

\section{Antioxidant activity of the pequi oil cream}

The antioxidant activity (AA) of the pequi oil cream evaluated by the DPPH method is shown in the Figure 3. In this test, the antioxidant activity was proportional to the concentration of pequi oil present in the cream.

From the regression curve, elaborated with the average values of the antioxidant activity as a function of the different concentrations analyzed, could be obtained the line equation $Y=7.7414 . X+27.39$, with linear regression coefficient of 0.9602 . From this equation, the antioxidant capability of the pequi oil cream of sequestering the $\mathrm{DPPH}^{\bullet}$ was also expressed by the $\mathrm{EC}_{50}$ value, which corresponds to the concentration of pequi oil required to reduce the $\mathrm{DPPH}^{\bullet}$ to $50 \%$ of the total hydrazine. The $\mathrm{EC}_{50}$ value of the emulsion with pequi oil was $2.921 \mathrm{mg} / \mathrm{mL}$. In order to calculate the $\mathrm{EC}_{50}$ value of quercetin, used as standard, it was first obtained its line equation, which had a value of $Y=10.257 . X-6.3158$, with linear regression coefficient $\left(R^{2}\right)$ of 0.9987 . Then, the $\mathrm{EC}_{50}$ value of quercetin could be determined as $0.005 \mathrm{mg} / \mathrm{mL}$.

From this result, it is possible to suggest that the intensity of this biological activity is probably correlated to the presence of phenolic compounds, given that these substances act as donors of hydrogen to highly reactive radicals, have antioxidant capacity and prevent cell death due to their chemical structure and reducing property [65]. According to Pereira [66], in the DPPH ${ }^{\bullet}$ test emulsions enriched with olive oils and grape seed, which have a high concentration of phenolic compounds, presented $E_{50}$ values of 1.76 and $2.30 \mathrm{mg} / \mathrm{mL}$, respectively. Thus, the emulsion with pequi oil presented a value close to $\mathrm{EC}_{50}$ when compared to the reported oils.

In order to confirm the antioxidant activity of the cream enriched with pequi oil, the ability to inhibit the lipoperoxidation process was evaluated. The Figure 3 shows that the pequi oil cream had an expressive ability to inhibit the lipid peroxidation process at the same concentrations analyzed in the DPPH test. Only the highest concentration sample of pequi oil cream $(6.25 \mathrm{mg} / \mathrm{mL})$ differed statistically from the others concentration samples. The lipid peroxidation method was validated by the cream enriched with $0.2 \mathrm{mg} / \mathrm{mL}$ quercetin, which showed an inhibition of $103.1 \%$.

The importance of these results should be considered as lipid peroxidation, induced by free radicals is one of the most significant molecular damages of the molecular degenerative metabolic process [67], and the pequi oil could retard cell aging. In addition, as phenolic compounds also have the ability to inhibit lipid 
peroxidation and lipoxygenase in vitro [68], it is likely that these metabolites are responding to the ability of pequi oil cream to inhibit this process.

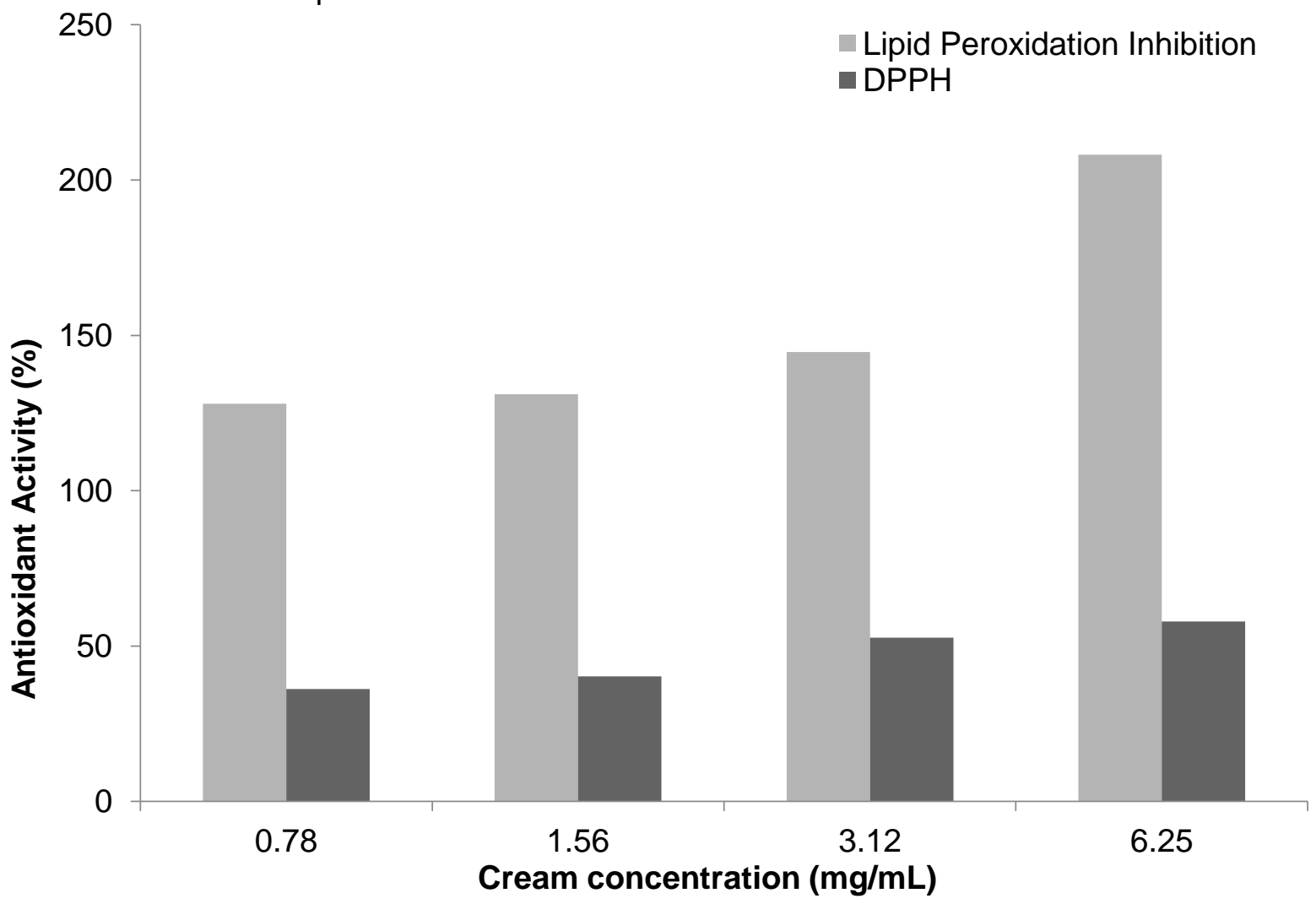

Figure 3. Mean $\pm S D$ of antioxidant activity of the pequi oil cream evaluated at four different concentrations by the $\mathrm{DPPH} \bullet$ method and by the ability of lipid peroxidation inhibition. One-way ANOVA followed by the Tukey's post-hoc test. The different letters indicate if there is a significant difference $(p<0.05)$ between the group.

\section{Pequi Oil Cream Sun Protection Factor (SPF)}

According to Saewan and coauthors [69], the presence of phenolic compounds in photoprotective emulsions take a prominent position in terms of the spectral absorption of the solar radiation in the UVB range with antiaging and photoprotection purposes [70]. The Mansur method, used to determine the sun protection factor (SPF), resulted the photoprotective activity of the pequi oil present in the formulation.

The SPF result presented by the pequi oil cream (SPF 11.40) is in accordance with the literature, which reports that plant products have the potential to be considered as sunscreens [71, 72], due to the capability of the chromophore groups present in plant products of absorbing radiant energy [73, 74]. It is worth to note that the pequi oil cream can be considered a photoprotector because it complies with the regulations of the Brazilian Health Regulatory Agency - Anvisa (RDC 30, dated June 1, 2012) [75], which determines that a sunscreen must have a minimum protection factor of 6 .

The association of synthetic sunscreen with pequi oil (SPF 30.00) did not show synergism capable of enhancing the photoprotective action of octyl methoxycinnamate, because this synthetic sunscreen was used as a positive control at the concentration of $5 \%(\mathrm{w} / \mathrm{w})$ and obtained the SPF value equal to 30.00 . Similar results were obtained in several studies that aimed to verify the photoprotective efficacy of plant extracts added to formulations containing synthetic sunscreens [73, 76-78].

Different, Busalacchi and coauthors [79] reported that the synergism is verified between synthetic sunscreens. The authors showed that the $(E, Z)$-2-ethylhexyl 2-cyano-3- (furan-2-yl) acrylate, an innovative UV radiation absorber synthetic, when added to a photoprotective formulation at a concentration of $5 \%(\mathrm{w} / \mathrm{w})$, increased the SPF values by about 2 units. In this way, this new molecule can be used in combination with other filters to enhance the photoprotective action of formulations.

\section{Quality of pequi cream}

Finally, considering the possibility of developing a phytocosmetic in accordance to the demands of the consumer market, the stability of the formulation enriched with pequi oil at the concentration of $6.25 \mathrm{mg} / \mathrm{mL}$ was evaluated. As negative control, was used the cream without the addition of the oil, denominated base cream. The first test performed was the centrifugation test, in which all analyzed formulations (pequi oil cream 
and base cream) did not present any movement of the dispersed particles upwards, that is, the creaming index was zero.

The following test evaluated the stability of the formulation in relation to thermal stress. It was possible to verify that only the samples of the cream enriched with pequi oil presented separation of phases when reaching the temperature of $80^{\circ} \mathrm{C}$, becoming biphasic. However, the two analyzed formulations showed coalescence upon returning to room temperature. It could be also observed a color change of the pequi oil cream, that became opaque and had the odor intensified. It is known that the surfactants decrease the interfacial tension between the internal and external phases of the emulsion, facilitating the phases mixing and the emulsion stability. However, it is already known that the severe increase in temperature in an emulsion causes the dehydration of the surfactant favoring the occurrence of coalescence [80]. Thus, as the pequi oil cream presented phase separation, besides the coalescence, it will be necessary to optimize the formulation and the proportion of the surfactants used.

The analysis of organoleptic characteristics during a period of 28 days under three different storage conditions (refrigerator, room temperature and oven) revealed that the color of the base cream, initially described as opaque white, changed to whitish and almost transparent when stored in the oven, by the $1^{\text {st }}$ day of analysis, and at room temperature, by the $21^{\text {st }}$ day. Thus, this tone change is associated with time and storage condition. These same variables similarly influenced the color of the cream enriched with pequi oil that changed from strong yellow to medium yellow by the $28^{\text {th }}$ day of the evaluation at room temperature and by the $8^{\text {th }}$ day in the oven. Nonetheless, it was possible to observe that the presence of pequi oil in the formulation delayed the appearance of the color change at room temperature and in the refrigerator.

In the evaluation of odor variation, both the base cream and the cream enriched with the pequi oil presented increased odor when stored in the oven. However, after the $2^{\text {nd }}$ day of analysis the odor normalized in the two creams being analyzed.

In relation to the analysis of the appearance of the formulations could be verified the influence of the high temperature on this characteristic. When stored in the oven, the base cream and pequi oil cream had their brightness reduced. Though, the presence of pequi oil in the formulation prevented the formation of grumes.

In the $\mathrm{pH}$ analysis, the measured values of the base cream and pequi oil creams did not present any statistically significant differences at all the storage conditions, even though the $\mathrm{pH}$ values differed for the pequi oil cream stored in the oven compared to samples storage at refrigerator and room temperature.

Regarding to spreadability, it was observed that the temperature variation due to storage conditions (refrigerator, room temperature and oven) did not affect this variable in the base cream and pequi oil creams. On the other hand, both the base cream and the pequi oil cream showed decrease of spreadability over the storage time. The data obtained in this study differ from those obtained by Friedrich and coauthors [81], who reported that the spreadability of non-ionic creams is always altered due to the different storage conditions, and are similar to the results presented by Czepula [82], which describe that non-ionic formulations always present reduction in the value of spreadability over time.

\section{CONCLUSION}

It was possible to realize that the pequi oil can be used in cosmetic formulations in the form of an emulsion, since it has shown to be free of toxicity. In addition, the cream enriched with pequi pulp oil showed high concentration of phenolic compounds and antioxidant and photoprotective properties. However, as the quality tests evidenced small changes in the organoleptic, physical-chemical and stability parameters, the composition of the formulation should be optimized to meet with the requirements of the consumer market.

Finally, the results showed that pequi oil can be converted in a product of great commercial value and, consequently, generate social and economic growth for the population that depends on this plant for its subsistence.

Funding: This research received no external funding.

Conflicts of Interest: The authors declare no conflict of interest.

\section{REFERENCES}

1. Saraf S, Kaur CD. Photoprotective phytoconstituents as novel cosmetics formulations. Pharmacogn. Rev. 2010; 4(7): 1-11.

2. Chermahini SH, Majid FAA, Sarmidi MR. Cosmeceutical value of herbal extracts as natural ingredients and novel technologies in anti-aging. J. Med. Plant. Res. 2011; 5(14): 3074-7. 
3. Balboa EM, Soto ML, Nogueira DR, Gonzalez-Lopez N, Conde E, Moure A, et al. Potential of antioxidant extracts produced by aqueous processing of renewable resources for the formulation of cosmetics. Ind. Crop. Prod. 2014; 58: 104-10.

4. Lubbe A, Verpoorte R. Cultivation of medicinal and aromatic plants for specialty industrial materials. Ind. Crop. Prod. 2011; 34(1): 785-801.

5. Tehranifar A, Selahvarzi Y, Kharrazi M, Bakhsh VJ. High potential of agro-industrial by-products of pomegranate (Punica granatum L.) as the powerful antifungal and antioxidant substances. Ind. Crop. Prod. 2011; 34(3): 1523-7.

6. Dhavamani S, Rao YPC, Lokesh BR. Total antioxidant activity of selected vegetable oils and their influence on total antioxidant values in vivo. Food Chem. 2014; 164: 551-5.

7. Nichols JA, Katiyar SK. Skin photoprotection by natural polyphenols: anti-inflammatory, antioxidant and DNA repair mechanisms. Arch. Dermatol. Res. 2010; 302(2): 71-83.

8. Stamatas GN, Sterke J, Hauser M, von Stetten O, van der Pol A. Lipid uptake and skin occlusion following topical application of oils on adult and infant skin. J. Dermatol. Sci. 2008: 50(2): 135-42.

9. Saraf $S$, Sahu S, Kaur CD, Saraf $S$. Comparative measurement of hydration effects of herbal moisturizers. Pharma. Res. 2010: 2(3): 146-451.

10. Cefali LL, Ataide JA, Moriel P, Foglio MA, Mazzola PG. Plant-based active photoprotectants for sunscreens. Int. J. Cosmet. Sci. 2016; 38(4): 346-53.

11. Scariot A, Sousa-Silva JC, Felfili JM. Cerrado: Ecology, Biodiversity and Conservation. Brasília: Ministério do Meio Ambiente; 2005.

12. Santos FS, Santos RF, Dias PP, Zanão Jr LA, Tomassoni F. The Pequi (Caryocar brasiliense Camb.) culture. Acta Iguazu. 2013; 2(3): 46-57.

13. Ribeiro RF. Pequi: the king of the cerrado. Belo Horizonte: Rede Cerrado; 2000.

14. Peixoto AR. The pequi and the agriculture in the Cerrado. In: Peixoto AR, editor. Arboreous oleaginous plant. São Paulo: Nobel; 1973. p. 197-226.

15. Almeida SP, Silva JA. [Piqui and buriti: food importance to the cerrado population]. Brasília: Documentos; 1994.

16. Lima A, Silva AMO, Trindade RA, Torres RP, Mancini-Filho J. Chemical composition and bioactive compounds present in pequi pulp and almond (Caryocar brasiliense Camb). Rev. Bras. Frutic. 2007; 29(3): 695-8.

17. Roesler R, Malta LG, Carrasco LC, Holanda RB, Sousa CAS, Pastore GM. [Antioxidant activity of cerrado fruit]. Ciênc. Tecnol. Aliment. 2007; 27(1): 53-60.

18. Vieira RF, Martins MVM. Genetic resources of Cerrado medicinal plants: a compilation of data. Rev. Bras. PI. Med. 2000; 3(1): 13-36.

19. Bezerra NKMS, Barros TL, Coelho NPMF. The action of pequi oil (Caryocar brasiliense) on the cicatricial process of skin lesions in rats. Rev. Bras. PI. Med. 2015; 17(4): 875-80.

20. Medaets JP, Greenhalgh AA, Lima ACMA, Souza DF. Family agriculture and sustainable use of native agrobiodiversity. Programa Biodiversidade Brasil Itália. Brasília: 2006; 172.

21. Oliveira E. Exploração de espécies nativas como uma estratégia de sustentabilidade socioambiental - o caso do pequi (Caryocar brasiliense Camb.) em Goiás [dissertation]. Brasília: Universidade de Brasília; 2006.

22. Pozo OVC. O pequi (Caryocar brasiliense): uma alternativa para o desenvolvimento sustentável do cerrado no norte de Minas Gerais [dissertation]. Lavras: Universidade Federal de Lavras; 1997.

23. Carrazza LR, D'Ávila JCC. Technological Manual of Integral Utilization of Pequi Fruit (Caryocar brasiliense). 2nd ed. Brasília: Instituto Sociedade, População e Natureza; 2010.

24. Angelo H, Pompamayer RDS, Viana MC, Almeida AND, Moreira JMMAP, Souza AND. [Economic valuation of the Pequi (Caryocar brasiliense Camb.) depredation in the brazilian Cerrado]. Sci. For. 2012; 40(93): 35-45.

25. Laufenberg G, Kunz B, Nystroem M. Transformation of vegetable waste into added products: $(A)$ the upgrading concept; (B) practical implementations. Bioresour. Technol. 2003; 87(2): 167-98.

26. Santos MJT. Aproveitamento de resíduos da indústria de óleos vegetais produzidos na Amazônia [dissertation]. Belém: Universidade Federal do Pará; 2014.

27. Maia EL. Otimização da metodologia para caracterização de constituintes lipídicos e determinação da composição química em ácidos graxos e aminoácidos de peixe em água doce [dissertation]. Campinas: Universidade Estadual de Campinas; 1992.

28. Mosmann T. Rapid colorimetric assay for cellular growth and survival: application to proliferation and cytotoxicity assays. J. Immunol. Methods. 1983; 65(1-2): 55-63.

29. Tsuboy MS, Marcarini JC, RC, Barros IB, Ferreira DT, Ribeiro LR, et al. In vitro evaluation of the genotoxic activity and apoptosis induction of the extracts of roots and leaves from the medicinal plant Coccolobamollis (Polygonaceae). J. Med. Food. 2010; 13(3): 503-8. 
30. Iha SM, Migliato KF, Vellosa JCR, Sacramento LVS, Pietro RCLR, Isaac VLB, et al. [Phytochemical study of guava (Psidium guajava L.) with antioxidant potential for the development of phytocosmetic formulation]. Rev. Bras. Farmacogn. 2008; 18(3): 387-93.

31. Allen JRL, Popovich N, Ansel H. Pharmaceutical forms and drug delivery systems. 8th ed. Porto Alegre: Artmed; 2007.

32. Rodrigues LM. Desenvolvimento e estudo de estabilidade preliminar de emulsões óleo/água (O/A) a base de óleos vegetais para prevenção e/ou adjuvante no tratamento de úlceras por pressão [dissertation]. Brasília: Universidade de Brasília; 2013.

33. Singleton VL, Rossi JA. Colorimetry of total phenolics with phosphomolybdic-phosphotungstic acid reagents. Am. J. Enol. Vitic. 1965; 16(3): 144-58.

34. Serdar G, Sökmen M, Demir E, Sökmen A, Bektaş E. Extraction of antioxidative principles of Achilleabiserrata M. Bieb. and chromatographic analyses. Int. J. Sec. Metabolite. 2015; 2(2): 3-15.

35. Brand-Williams W, Cuvelier ME, Berset C. Use of a free radical method to evaluate antioxidant activity. Food Sci. and Techn. 1995; 28(1): 25-30.

36. Daker M, Abdullah N, Vikineswary S, Goh PC, Kuppusamy UR. Antioxidant from maize and maize fermented by Marasmiellus sp. as stabiliser of lipid-rich foods. Food Chem. 2008; 107(3): 1092-8.

37. Li X, Shi X, Jin Y, Ding F, Du Y. Controllable antioxidative xylan-chitosan Maillard reaction products used for lipid food storage. Carbohydr. Polym. 2013; 91(1): 428-33.

38. Ruvolo Júnior EC. Sun protection: comparison of methods of determination by tests in humans (in vivo) FDA, COLIPA, SAA. Cosmet. Online. 1997; 19(105): 37-46.

39. Mansur JS, Breder MNR, Mansur MCA, Azulay RD. Determination of the sun protection factor by spectrophotometry. An. Bras. Dermatol. 1986; 61: 121-4.

40. Velasco MVR, Balogh TS, Pedriali CA, Sarruf FD, Pinto CASO, Kaneko TM, et al. New analytical methodologies for evaluating photoprotective (in vitro) efficacy - review. Rev. Cienc. Farm. Básica Apl. 2011; 32(1): 27-34.

41. Barth AL. Fator de proteção solar versus coeficiente de carga de filtros solares químicos: avaliação fotobiológica de uma mistura de filtros solares químicos [dissertation]. Rio de Janeiro: Universidade Federal do Rio de Janeiro; 2000.

42. Garcia S, Santos EP. Evaluation of SPF of commercial products by in vitro method. Rev. Bras. Farm.1990; 71(4): 99.

43. Velasco MVR, Sarruf FD, De Oliveira CA, Da Silva APM, Consiglieri VO, Kaneko TM, et al. Influences of bioactive substances on the physicochemical and functional stability of sunscreen emulsions. Biomed. Biopharm. Res. 2012; (9) 1: 119-30.

44. Ferreira RM, Zatti RA. Protocol for physical-chemical stability tests of phytocosmetic. Anais V SIMPAC; Viçosa: 2015; 5(1): 493-500.

45. Lachman L, Hanna AS, Lin K. Controle e garantia de qualidade. In: Lachman L, Lieberman HA, Kanig JL, editor. Teoria e Prática na Indústria Farmacêutica. Lisboa: Fundação Calouste Gulbenkian; 2001.

46. Cicero N, Albergamo A, Salvo A, Bua GD, Bartolomeo G, Rotondo VMA, et al. Chemical characterization of a variety of cold-pressed gourmet oils available on the Brazilian market. Food Res. Int. 2018; 109: 517-525.

47. Nascimento-Silva NRR, Naves MMV. Potential of Whole Pequi (Caryocar spp.) Fruit - Pulp, Almond, Oil and Shell - as a Medicinal Food. J. Med. Food. 2019; 00(0): 1-11.

48. Penagos-Calvete D, Duque V, Marimon C, Parra DM, restrepo-Arango SK, Scherf-Clavel O, Holzgrabe U, Montoya G, Salamanca $\mathrm{CH}$. Glycerolipid Composition and Advanced Physicochemical Considerations of Sacha Inchi Oil toward Cosmetic Products Formulation. Cosmetics. 2019; 6(4): 70.

49. Anwar F, Hussain Al, lqbal S, Bhanger MI. Enhancement of the oxidative stability of some vegetable oils by blending with Moringa oleifera oil. Food Chem. 2007; 103(4): 1181-91.

50. Kim J, Kim DN, Lee SH, Yoo SH, Lee S. Correlation of fatty acid composition of vegetable oils with rheological behaviour and oil uptake. Food Chem. 2010; 118(2): 398-402.

51. Ferreira BS, Almeida CG, Faza LP, Almeira A, Diniz CG, Silva VL, et al. Comparative properties of Amazonian oils obtained by different extraction methods. Molecules. 2011; 16(7): 5875-5885.

52. Siger A, Nogala-Kalucka M, Lampart-Szczapa E. The content and antioxidant activity of phenolic compounds in cold-pressed plant oils. J. Food Lipids. 2008; 15(2): 137-49.

53. Jorge N, Da Silva AC, Aranha CPM. Antioxidant activity of oils extracted from orange (Citrus sinensis) seeds. An. Acad. Bras. Ciênc. 2016; 88(2): 951-8.

54. Malacrida CR, Jorge N. Fatty acids and some antioxidant compounds of Psidium guajava seed oil. Acta Aliment. 2013; 42(3): 371-8. 
55. Ghazani SM, Marangoni AG. Minor compoents in canola oil and effects of refining on these constituents: a review. J. Am. Oil Chem.' Soc. 2013;90(7): 923-32.

56. Vujasinovic V, Djilas S, Dimic E, Romanic R, Takaci A. Shelf life of cold-pressed pumpkin (Cucurbita pepo L.) seed oil obtained with screw press. J. Am. Oil Chem.' Soc. 2010;87(12): 1497-505.

57. Branco VNC. Transformações químicas na oxidação acelerada de óleos vegetais e sua relação com a capacidade antioxidante total, uma abordagem multivariada [dissertation]. Rio de Janeiro: Universidade Federal do Rio de Janeiro; 2013.

58. Smeriglio A, Galati EM, Monforte MT, Lanuzza F, D'Angelo V, Circosta C. Polyphenolic Compounds and Antioxidant Activity of Cold-Pressed Seed Oil from Finola Cultivar of Cannabis sativa L. Phytother. Res. 2016;30(8):1298-1307.

59. Adaramola B, Onigbinde A, Shokunbi O. Physiochemical properties and antioxidant potential of Persea Americana seed oil. Chem. Int. 2016;2(3):168-75.

60. Bouyahya A, Dakka N, Talbaoui A, Moussaoui N E, Abrini J, Bakri Y. Phenolic contents and antiradical capacity of vegetable oil from Pistacia lentiscus (L). J. Mater. Environ. Sci. 2018;9(5):1518-24.

61. Dang TQ, Nguyen TKK. Impact of extraction method on the oil yield, physicochemical properties, fatty acid composition and stability of cashew nut (Anacardium occidentale L.) oil. EC Nutrition. 2019;14:165-71.

62. Rezig L, Chouaibi M, Ojeda-Amador RM, Gomez-Alonso S, Salvador MD, Fregapane G, et al. Cucurbita maxima pumpkin seed oil: from the chemical properties to the different extracting techniques. Not. Bot. Horti Agrobo. ClujNapoca. 2018;46(2): 663-9.

63. Barreto GPM, Benassi MT, Mercadante AZ. Bioactive Compounds from Several Tropical Fruits and Correlation by Multivariate Analysis to Free Radical Scavenger Activity. J. Braz. Chem. Soc. 2009;20(10):1856-61.

64. Ribeiro PT. Desenvolvimento de emulsões utilizando extrato seco de Passiflora nitida Kunth [dissertation]. Manaus: Universidade Federal do Amazonas; 2015.

65. Beiryureilai M, Lalrinzuali K, Jagetia GC. Determination of Anti-Inflammatory and Analgesic Activities of a Citrus Bioflavonoid, Hesperidin in Mice. Immunochem. Immunopathol. 2015; 1(107): 1-7.

66. Pereira GG. Obtenção de nanoemulsões $\mathrm{O} / \mathrm{A}$ à base de óleo de semente de uva e oliva aditivadas de metoxicinamato de octila e estudo do potencial antioxidante e fotoprotetor das emulsões [dissertation]. Ribeirão Preto: Universidade de São Paulo; 2008.

67. Lima ES, Abdalla DSP. [Lipid peroxidation: mechanisms and evaluation in biological samples]. Rev. Bras. Ciênc. Farm. 2001; 37(3): 293-30.

68. Sousa CMM, Silva HR, Vieira-Jr GM, Ayres MCC, Costa CLS, Araújo DS, et al. [Total phenols and antioxidant activity of five medicinal plants]. Quím. Nova. 2007; 30(2): 351-5.

69. Saewan N, Jimtaisong A. Photoprotection of natural flavonoids. J. Appl. Pharm. Sci. 2013; 3(9): 129-41.

70. Orlanda JFF, Vale VV. [Phytochemical analysis and photoprotective activity of ethanolic extract of Euphorbia tirucalli Linneau (Euphorbiaceae)]. Rev. Bras. PI. Med. 2015; 17(4): 730-6.

71. Polonini HC, Raposo NRB, Brandão MAF. [Natural photoprotectors as an instrument of primary action in the prevention of skin cancer]. Rev. APS. 2011; 14(2): 216-23.

72. Nascimento CS, Nunes LCC, De Lima ÁAN, Grangeiro Júnior S, Rolim Neto PJ. [Improving of FPS in sunscreen formulation using green and red propolis extracts]. Rev. Bras. Farm. 2009; 30(1): 334-9.

73. Violante IMP, Souza IM, Venturini CL, Ramalho AFS, Santos RAN, Ferrari M. [Preliminary study of the in vitro photoprotective activity of plant extracts from the cerrado of Mato Grosso]. Rev. Bras. Farm. 2008; 89(3): 175-9.

74. Maillan P, Gripp A, Sit F, Jermann R, Wefenfelder H. Protecting against UV - induced degradation and enchancing shine. Cosmet Toiletries. 2005; 120(3): 65-71.

75. Brasil. Agência Nacional de Vigilância Sanitária. Resolução RDC n. 30, de 1 de junho de 2012. Dispõe sobre Regulamento Técnico Mercosul sobre Protetores Solares em Cosméticos. Diário Oficial da União, Poder Executivo, de 4 de junho de 2012.

76. Mansur MCPPR. Estudo preliminar das atividades fotoprotetora e antioxidante dos extratos das folhas de Bauhinia microstachya var. massambabensis Vaz numa formulação antissolar [dissertation]. Rio de Janeiro: Universidade Federal do Rio de Janeiro; 2011.

77. Munhoz VM, Lonni AASG, Mello JCP, Lopes GC. [Evaluation of the sun protection factor in photoprotectors plus extracts of the Brazilian flora rich in phenolic substances]. Rev. Ciênc. Farm. Básica Apl. 2012; 33(2): 225-32.

78. De Souza FP, Campos GR, Packer JF. [Determination of photoprotective and antioxidant activity in emulsions containing Malpighia glabra L. extract - Acerola]. Rev. Ciên. Farm. Básica Apl. 2013; 34(1): 69-77.

79. Busalacchi G, Beverina L, Lionetti N, Rigano L. Development of an Innovative and Eco-Friendly UV Radiation Absorber, Based on Furan Moieties. Cosmetics. 2020; 7(1): 6.

80. Bonadeo I. [Cosmetology science and technology]. Madri: Editorial Ciência; 1982. 
81. Friedrich M, Primo FT, Funck JAB, Laporta LV, Alves MP, Bittencourt CF, et al. [Physical-chemical stability evaluation of non-ionic cream inscribed in the National Formulary]. Lat. Am. J. Pharm. 2007; 26(4): 558-62.

82. Czepula AIS. Desenvolvimento de preparações semi-sólidas contendo extrato de Sphagneticolatrilobata (L.) Pruski (Acmela brasiliensis, Wedelia paludosa) (ASTERACEAE) e avaliação da atividade anti-inflamatória tópica in vivo [dissertation]. Itajaí: Universidade do Vale do Itajaí; 2006.

(C) $(1) 2020$ by the authors. Submitted for possible open access publication under the terms and
conditions of the Creative Commons Attribution (CC BY NC) license (https://creativecommons.org/licenses/by-nc/4.0/). 